\title{
CPC USP: A PRESERVAÇÃO CULTURAL E A EXTENSÃO UNIVERSITÁRIA
}

A Revista CPC desde sua criação, em 2006, para além do papel de difusor das pesquisas acadêmicas relativas à preservação cultural, vem cumprindo o importante papel de compartilhar as experiências desenvolvidas pelo Centro de Preservação Cultural da Universidade de São Paulo (CPC) no âmbito da extensão universitária. O vínculo do CPC à Pró-Reitoria de Cultura e Extensão Universitária e sua sede na Casa de Dona Yayá, no bairro da Bela Vista (Bixiga), oferecem condições privilegiadas para trabalhos envolvendo novas problemáticas e outros personagens, das quais o CPC tem sabido tirar proveito para o aprofundamento do conhecimento científico. A perseverança na continuidade dos trabalhos que tem caracterizado sua trajetória propicia ao CPC desenvolver algumas sínteses e estabelecer algumas parcerias importantes para a consolidação de sua participação na dinâmica da cidade de modo geral, e do Bixiga em particular.

Frente à diversidade do patrimônio cultural da USP e da complexidade de sua preservação, o CPC elaborou o documento "Carta Patrimonial da USP”, apresentado nesta edição, uma dessas sínteses que revela a dinâmica dos trabalhos do CPC. Resultado de um trabalho coletivo referendado em um fórum aberto e que tem por objetivo aproximar todos os envolvidos à questão do seu próprio patrimônio, bem como estabelecer alguns parâmetros para a sua conservação. 
A mudança da sede do CPC da Cidade Universitária Armando Salles de Oliveira para a Casa de Dona Yayá, em 2004, abriu um amplo leque de novas possibilidades de investigação. Seus diretores, a partir de então, Ana Lucia Duarte Lanna, Maria Lúcia Bressan Pinheiro, José Tavares Correia de Lira, vêm investindo no estreitamento dessa relação com o bairro, notadamente por meio das pesquisas "Imigrantes", coordenada pela profa. Ana Lanna, e "Bixiga: artes e ofícios", sob a orientação da profa. dra. Rose Satiko; e recentemente a realização do seminário "Bixiga: patrimônio cultural", que reuniu pesquisadores, usuários, moradores e trabalhadores em uma tentativa de aproximação de todos os envolvidos para uma ação conjunta para a preservação do bairro. A notícia sobre o evento consta desta edição. Essa aproximação ao bairro mereceu a premiação do CPC-Casa de Dona Yayá pela Associação Paulista dos Críticos de Arte (APCA), entre os melhores de 2017, na categoria Resistência Urbana da área de Arquitetura, ao lado da Escola de Samba Vai-Vai, do Teatro Oficina, da União das Mulheres e da Festa de Nossa Senhora Achiropita.

Dois eventos também registrados nesta edição revelam a abrangência dos trabalhos de extensão promovidos pelo CPC. A exposição "Sesmaria de Passarinhos", baseada no trabalho do Grupo Ururay, que constitui uma das iniciativas mais importantes no reconhecimento do patrimônio cultural da zona leste da cidade de São Paulo; e o seminário internacional "Domesticidade, Gênero e Memória", que é um desdobramento do encontro organizado pelo CPC, em 2014, e confirma a pertinência do debate sobre esse tema.

Quanto aos artigos que integram esta edição da Revista CPC, mais uma vez ilustram a diversidade de temas, autores e procedências, e comprovam o alcance da revista. De ruínas a estações ferroviárias, do Piauí à Argentina, de equipamentos esportivos a coleções de diapositivos, os artigos a seguir contribuem para a reflexão sobre o patrimônio cultural.

$\mathrm{O}$ artigo A problemática da ruína nas teorias da preservação patrimoniais do século XIX ao restauro crítico, no qual Angela Rosch Rodrigues questiona a influência do reconhecimento do estado de ruína no processo de preservação de um bem cultural e como esses remanescentes são tratados pelos teóricos da preservação, desde o século XIX até a promulgação da Carta de Veneza, em 1964. 
María Sabina Uribarren, em A preservação do patrimônio brasileiro nos boletins da Comisión Nacional de Museos, Monumentos y Lugares Históricos da Argentina, tendo como fonte dois textos publicados na Argentina no início da década de 1940, traz novos elementos que contribuem para a identificação de um círculo de relações latino-americanas no âmbito do patrimônio cultural, permitindo novas leituras sobre o Serviço do Patrimônio Histórico e Artístico nacional (SPHAN).

O artigo Cartografia social no território do Parque Nacional Serra da Capivara: mapeamento participativo para retomada da terrototialidade, desenvolvido por Marian Helen da Silva Gomes Rodrigues, Jorlan da Silva Oliveir, Juliana Mercuri e Pedro Diniz Coelho de Souza, traz alguns resultados do trabalho que está sendo elaborado com a participação dos moradores da área do parque, e propõe uma reinterpretação da territorialidade local dos lugares de vivência cotidiana dessa comunidade.

A análise apresentada no artigo Estações da antiga Estrada de Ferro Noroeste do Brasil: o caso de Bauru - SP, por Ludmilla Sandim Tidei de Lima Pauleto, discorre sobre as condições atuais da edificação, estabelecendo algumas diretrizes para futuras intervenções.

Bianca Manzon Lupo, em Estádio do Pacaembu: do palco de emoções ao gigante sem dono recupera o significado histórico desse bem cultural, importante referência da sociedade paulistana, e o confronta com os parâmetros internacionais que determinam o "padrão FIFA" para os equipamentos esportivos.

O artigo Gestão do Acervo Arquiteto Eduardo Kneese De Mello: relato do tratamento organizacional da coleção iconográfica, ao trazer a público a estrutura do trabalho para a organização dessa coleção fortalece o canal de comunicação entre pesquisadores, permitindo, pela troca de ideias, o aperfeiçoamento dos métodos empregados, bem como suscitando novas experimentações.

Encerra esta edição a entrevista realizada por Luciana Guizan Aureliano com Celina Albano sobre a Interpretação do patrimônio no Brasil.

A todos uma boa leitura,

Mônica Junqueira de Camargo. 